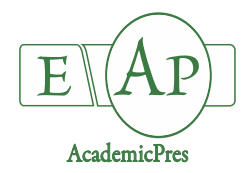

Cheng W-J et al. (2020)
Notulae Botanicae Horti Agrobotanici Cluj-Napoca 48(4):2021-2031
DOI:10.15835/48412144
Research Article



\title{
Effects of five mycorrhizal fungi on biomass and leaf physiological activities of walnut
}

\section{Wei-Jin $\mathrm{CHENG}^{1}$, Yong-Jie $\mathrm{XU}^{2 *}$, Guang-Ming $\mathrm{HUANG}^{3}$, Mohammed M. RAHMAN ${ }^{4}$, Zhi-Yan XIAO ${ }^{1}$, Qiang-Sheng WU ${ }^{3 *}$}

\author{
${ }^{1}$ Wuhan Forestry Workstation, Wuhan, 430023, China; 914263569@qq.com; 346445013@qq.com \\ ${ }^{2}$ Hubei Academy of Forestry, Wuhan, Hubei 430075, China; 498674563@qq.com ( ${ }^{*}$ corresponding author) \\ ${ }^{3}$ Yangtze University, College of Horticulture and Gardening, Jingzhou, Hubei 434025, China; 1072149158@qq.com; \\ wuqiangsh@163.com (*corresponding author) \\ ${ }^{4}$ Tokyo Gakugei University, Natural Science Unit, Koganei, Tokyo 184-8501, Japan; mmrahman@u-gakugei.ac.jp
}

\begin{abstract}
Arbuscular mycorrhizal fungi (AMF) can benefit many plants, but their effects on walnuts are not yet known. The present study aimed to analyze the effect of five AMF species, namely, Acaulospora scrobiculata, Diversispora spurca, Glomus etunicatum, $G$. mosseae and $G$. versiforme on biomass production, chlorophyll contents, sugar fraction contents, and mineral element contents of walnut (Juglans regia L.) seedlings. The five AMF species colonized roots of walnut, established mycorrhizas in roots and hyphae in soil, and released easily extractable glomalin-related soil protein into soil, whilst $D$. spurca exhibited the best effect. All the AMF inoculations, except $A$. scrobiculata, stimulated shoot and root biomass production. Mycorrhizal fungal inoculations collectively increased leaf chlorophyll $a$, chlorophyll $b$, and total chlorophyll $a+b$ concentrations, and thus promoted leaf sucrose accumulation, which provides an important mycorrhiza-carbon source to roots. AMF inoculations conferred a positive effect on leaf $\mathrm{N}, \mathrm{P}, \mathrm{K}, \mathrm{Mg}, \mathrm{Fe}, \mathrm{B}, \mathrm{Zn}$ and $\mathrm{Cu}$ contents, while they reduced leaf $\mathrm{Mn}$ contents. These results concluded that AMF were beneficial to the growth and physiological activities of walnut, which gives the support for the AMF application in walnut.
\end{abstract}

Keywords: arbuscular mycorrhiza; mineral nutrition; photosynthate; walnut

\section{Introduction}

Walnut (Juglans regia L.) is an important economy forest in many countries of the world. Walnut is often grown in mountainous areas where the soil is very poor, limiting the yield and physiological activities of walnut (Pati and Mukhopadhyay, 2009; Qin et al., 2011; Wang et al., 2016; Bu et al., 2019; Zou et al., 2019; Kong et al., 2020). To adapt to the soil environment, plants coexist with soil microorganisms such as arbuscular mycorrhizal fungi (AMF) to improve nutrient acquisition (López-Ráez et al., 2010; Latef and Chaoxing, 2011; Gill et al., 2016; Wu et al., 2019b, 2020). AMF are a kind of soil inhabiting endophytic fungi, which form arbuscular mycorrhizal symbiosis with roots of $80 \%$ of land's plants. Arbuscular mycorrhizas are able to stimulate nutrient absorption, improve plant growth, and enhance stress tolerance of host plants (Wu et al., 2013; Adolfsson et al., 2017; He et al., 2019; Moreira et al., 2019; Rosolino et al., 2019; Zhang et al., 2020; Zou 
et al., 2020; Yang et al., 2021). In switchgrass plants, inoculation with Rhizophagus irregularis improved K, Mg, and $\mathrm{Na}$ contents in shoots (Sun and Yang, 2019). Native AMF isolated from field citrus significantly accelerated P, K, Mg, and Zn contents in leaves of trifoliate orange seedlings (Wu et al., 2019). Mathur et al. (2018) reported that $R$. intraradices, Funneliformis mosseae, and F. geosporum promoted the synthesis of chlorophyll probably by increasing Mg uptake. However, Glomus clarum showed a negative effect on $\mathrm{Mn}$ contents in sour orange (Ortas et al., 2002). Arines et al. (1990) also reported that inoculating G. mosseae or G. aggregatum significantly decreased Mn contents in red clover. As a result, more attention should be paid to the effect of AMF on nutrient uptake of host plants.

Earlier studies have shown that the survival of walnut plants in nursery was significantly improved after inoculation with G. intraradices or G. mosseae (Dolcet-Sanjuan et al., 1996). G. deserticola also improved leaf area and root weight in Juglans nigra (Dixon, 1988). In addition, inoculation with Gigaspora margarita, $G$. deserticola, and G. etunicatum markedly stimulated N, P, and K concentrations in leaves of J. nigra (Dixon, 1988). Behrooz et al. (2019) found that inoculation with $G$. mosseae and G. etunicatum alleviated drought stress of walnut. These studies indicated that AMF co-exist well with walnut, to promote its growth and to enhance stress tolerance. However, the effect of AMF on walnut has been little studied and needs to be further explored.

The aims of the present study were to evaluate the effects of five AMF species from three genera on biomass production, chlorophyll concentrations, sugar contents, and mineral element contents of walnut.

\section{Materials and Methods}

\section{Experimental design}

This experiment was conducted in completely randomized design with six inoculations with Acaulospora scrobiculata, Diversispora spurca, Glomus etunicatum, G. mosseae, G. versiforme and non-AMF control. Each treatment was replicated six times, resulting in a total of 36 pots.

\section{Plant set-up}

Seeds of Juglans regia L. Liaohe 1 were sterilized with $75 \%$ alcohol for $10 \mathrm{~min}$, sowed in autoclaved $(0.11$ $\mathrm{MPa}, 121^{\circ} \mathrm{C}, 2 \mathrm{~h}$ ) sand, and germinated in an incubator at $28{ }^{\circ} \mathrm{C} / 20{ }^{\circ} \mathrm{C}$ (day/night temperature) and $80 \%$ relative humidity. A month later, one seedling with uniform size and two-leaf-old was transferred into a 2.1-L plastic pot that was supplied with $2.1 \mathrm{~kg}$ autoclaved soil and sand $(3: 1, \mathrm{v} / \mathrm{v})$. When the seedlings were transplanted, mycorrhizal fungi were inoculated. Five AMF species were Acaulospora scrobiculata Trappe, Diversispora spurca (C.M. Pfeiff., C. Walker \& Bloss) C. Walker \& A. Schüßler, Glomus etunicatum Becker \& Gerd., Glomus mosseae (Nicolson \& Gerd.) Gerd. \& Trappe, and Glomus versiforme (P. Karst.) S.M. Berch, which were provided by the Bank of Glomales in China (BGC, Beijing, China). These fungi were propagated with white clover as the host plant for 3 months under potted conditions. Mycorrhizal fungal inoculums consisted of spores, sporocarps, AMF-colonized root segments, soil hyphae, and the growth substrate. For AMF inoculation, $100 \mathrm{~g}$ of mycorrhizal inoculum was applied to the rhizosphere of potted walnut seedlings. NonAMF treatment received $100 \mathrm{~g}$ sterilized mycorrhizal inoculum. The seedlings were subsequently placed in a greenhouse with $720 \mu \mathrm{mol} / \mathrm{m}^{2} / \mathrm{s}$ average photon flux density, $28 / 20{ }^{\circ} \mathrm{C}$ day/night temperature, and $67 \%$ relative humidity from March to June, 2019.

\section{Parameter determinations}

At harvest time, the growth of walnut seedlings with different treatments showed a significant difference. The walnut seedlings were divided into the shoot and the root, and their fresh weight was measured. Subsequently, a small amount of root segments with $1-\mathrm{cm}$-long were stained according to the protocol as described by Phillips and Hayman (1970). The root AMF colonization degree was estimated as the percentage 
of AMF-infected root lengths versus total root lengths. Soil mycorrhizal hyphal length was determined using the procedure as outlined by Bethlenfalvay and Ames (1987). Soil easily extractable glomalin-related soil protein (EE-GRSP) was assayed by He et al. (2020).

Leaf chlorophyll $a$, chlorophyll $b$, total chlorophyll (chlorophyll $a+b$ ), and carotenoid concentrations were calculated by Arnon (1949) using the $80 \%$ acetone solution.

Leaf samples were dried to a constant weight in air oven at $75^{\circ} \mathrm{C}$ for 48 and ground into $0.5 \mathrm{~mm}$ powder, which was used for the analysis of sugars and mineral nutrients. Leaf glucose, fructose, and sucrose contents were determined by Wu et al. (2015). The sieved leaf samples were digested by $\mathrm{H}_{2} \mathrm{SO}_{4}-\mathrm{H}_{2} \mathrm{O}_{2}$ and subjected to chemical analysis by an Electrochemical Analyzer (Smartchem 200) for $\mathrm{N}$ contents and by an ICP Specmometer (IRIS Advantage) for other mineral element contents.

\section{Statistical analysis}

Data were analyzed using the one-way analysis of variance with the SAS software (SAS Institute, Inc., Cary, NC, USA). The Duncan's Multiple Range Test at the 0.05 level was utilized to compare the significant difference among six treatments.

\section{Results and Discussion}

\section{Changes in mycorrhizal status in roots and soils}

There was not any mycorrhizal colonization found in the roots of the non-AMF-treated seedlings, while the root colonization of the seedlings inoculated with A. scrobiculata, D. spurca, G. etunicatum, G. mosseae and $G$. versiforme ranged from $46.0 \%$ to $76.4 \%$ (Table 1). Similarly, soil mycorrhizal hyphae were not observed in the non-AMF seedlings, but in the AMF-inoculated seedlings, varied from $1.30 \mathrm{~m} / \mathrm{g}$ to $1.65 \mathrm{~m} / \mathrm{g}$. Moreover, the seedlings colonized by $D$. spurca, G. etunicatum, G. mosseae and $G$. versiforme exhibited significantly higher soil EE-GRSP concentrations, whereas $A$. scrobiculata did not significantly alter soil EE-GRSP concentrations, compared with non-AMF controls. Among them, mycorrhizal status in soil and root was the highest under the condition of D. spurca. As proposed by Davoodian et al. (2012), D. spurca had better compatibility with walnut seedlings than others AMF species. Previous studies have demonstrated that root AMF colonization was positively correlated with improvement of plant growth and $\mathrm{P}$ acquisition (Treseder and Kathleen, 2013). García-González et al. (2016) recommended soil EE-GRSP concentration as one indicator of mycorrhizal status. The correlation analysis also showed that there was a significant positive correlation between root mycorrhizal colonization and soil mycorrhizal hyphal length or soil EE-GRSP concentration (Figure 1), which was consistent with previous studies conducted by Curaqueo et al. (2010) and Wu et al. (2012). Glomalin is released into the soil to increase soil EE-GRSP concentrations for contributing nutrient cycle, when the mycorrhizal hyphae and spores senescenced or died (He et al., 2020; Meng et al., 2020).

Table 1. Root AMF colonization, soil hyphal length, and soil easily extractable glomalin-related soil protein (EE-GRSP) of walnut (Juglans regia L. Liaohe 1) seedlings after inoculated with Acaulospora scrobiculata, Diversispora spurca, Glomus etunicatum, G. mosseae, G. versiforme, and non-AMF

\begin{tabular}{|c|c|c|c|}
\hline AMF treatments & Root AMF colonization (\%) & Soil hyphal length $(\mathrm{m} / \mathrm{g})$ & Soil EE-GRSP $(\mathrm{mg} / \mathrm{g})$ \\
\hline A. scrobiculata & $54.97 \pm 1.76 \mathrm{c}$ & $1.42 \pm 0.12 \mathrm{~b}$ & $0.43 \pm 0.04 \mathrm{~cd}$ \\
\hline D. spurca & $76.37 \pm 6.70 \mathrm{a}$ & $1.65 \pm 0.10 \mathrm{a}$ & $0.58 \pm 0.04 \mathrm{a}$ \\
\hline G. etunicatum & $63.61 \pm 5.53 \mathrm{~b}$ & $1.48 \pm 0.14 \mathrm{ab}$ & $0.51 \pm 0.04 \mathrm{~b}$ \\
\hline G. mosseae & $51.57 \pm 0.97 \mathrm{~cd}$ & $1.63 \pm 0.10 \mathrm{a}$ & $0.48 \pm 0.04 \mathrm{bc}$ \\
\hline G. versiforme & $46.99 \pm 0.68 \mathrm{~d}$ & $1.30 \pm 0.10 \mathrm{~b}$ & $0.52 \pm 0.04 \mathrm{~b}$ \\
\hline Non-AMF & $0 \pm 0 \mathrm{e}$ & $0 \pm 0 \mathrm{c}$ & $0.38 \pm 0.03 \mathrm{~d}$ \\
\hline
\end{tabular}

Data (means $\pm \mathrm{SD}, n=6)$ followed by different letters above the bars indicate significant differences $(P<0.05)$ among treatments. 


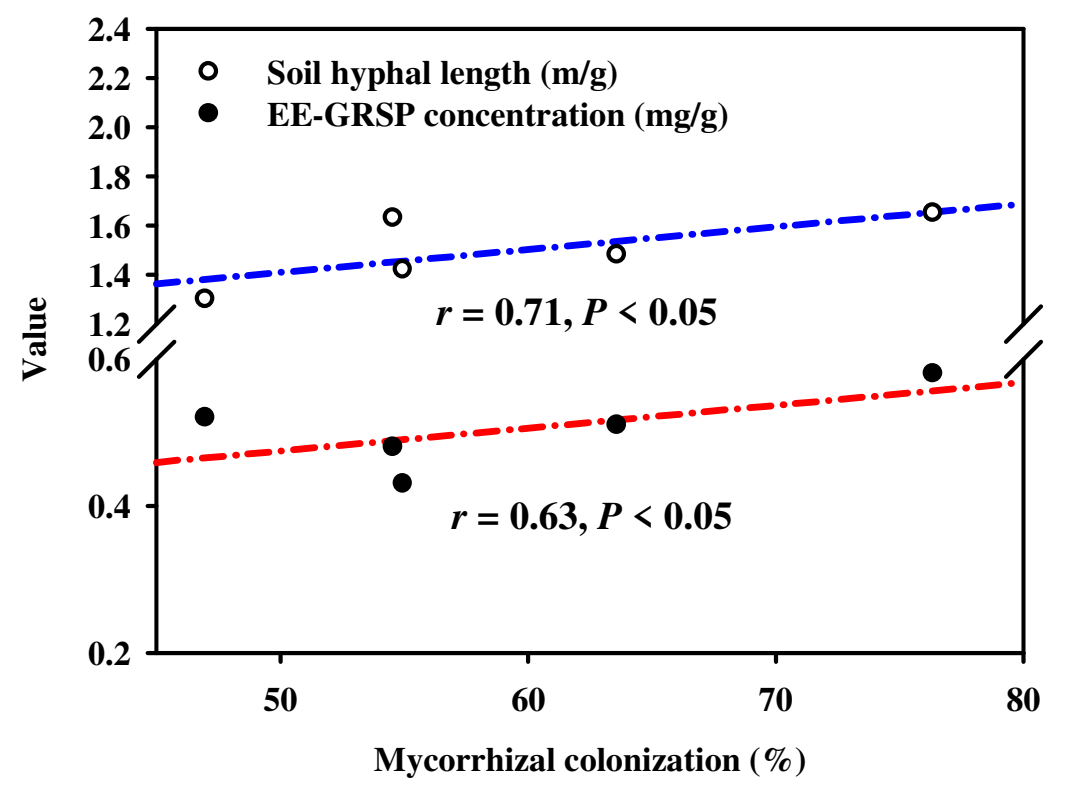

Figure 1. Linear regression between root mycorrhizal colonization and soil hyphal length or EE-GRSP concentration of walnut (Juglans regia L. Liaohe 1) seedlings

\section{Changes in biomass production}

The results of this study showed that the shoot and root biomass was positively impacted by AMF colonization (Figure 2). Compared to the non-AMF treatment, shoot and root biomass was significantly respectively increased by $54.6 \%$ and $42.9 \%$ with $D$. spurca, by $43.1 \%$ and $14.3 \%$ with G. etunicatum, by $22.7 \%$ and $6.5 \%$ with $G$. mosseae, and by $26.0 \%$ and $28.6 \%$ with $G$. versiforme. Meanwhile, A. scrobiculata did not significantly alter shoot and root biomass, and $D$. spurca exhibited the best promoted effect. Earlier results by Giri et al. (2003) showed a significant increase in shoot and root biomass in Acacia auriculiformis plants inoculated with $G$. fasciculatum or $G$. macrocarpum. In tea plants, mycorrhiza-improved plant biomass depended on AMF species (G. etunicatum, D. spurca, G. versiforme, and mixed-AMF) (Shao et al., 2018). Also, G. etunicatum, $G$. mosseae, and a mix-AMF had notably positive effect on biomass of walnut (Behrooz et al., 2019). Combining these previous results with our study, it can be seen that mycorrhizas could stimulate plant biomass production of walnut, dependent on AMF species, whilst $D$. spurca had the best effect.

\section{Changes in chlorophyll and carotenoid concentrations}

The present study showed that compared to non-AMF control, all the mycorrhizal fungal inoculations significantly increased leaf chlorophyll $a$, chlorophyll $b$, carotenoid, and total chlorophyll concentration, except no changes in carotenoid concentrations between $G$. versiforme inoculation and non-AMF treatment (Table 2). Compared with the non-AMF seedlings, chlorophyll $a$, chlorophyll $b$, carotenoid, and total chlorophyll contents were increased by $36.0 \%, 38.3 \%, 28.6 \%$, and $36.1 \%$ in $A$. scrobiculata-inoculated seedlings, by $65.0 \%$, $68.1 \%, 57.1 \%$, and $66.0 \%$ in $G$. etunicatum-inoculated seedlings, by $68.0 \%, 63.8 \%, 51.4 \%$, and $66.0 \%$ in $G$. mosseae-inoculated seedlings, by $53.0 \%, 53.2 \%, 51.4 \%$, and $53.1 \%$ in $D$. spurca-inoculated seedlings, and by $19.0 \%, 70.2 \%, 11.4 \%$, and $34.7 \%$ with $G$. versiforme-inoculated seedlings. This result was in agreement with Baslam et al. (2013) and, Tuo et al. (2015), and Ekanayake et al. (2015). Chlorophyll and carotenoid have the function of absorbing and transmitting luminous energy (Fester et al., 2005). Better chlorophyll levels in 
mycorrhizal plants are involved in higher photosynthates and $\mathrm{N}, \mathrm{Fe}$, and $\mathrm{Mg}$ contents in mycorrhizal plants (Tuo et al., 2015), as seen in Table 3 and Table 4 in our study.

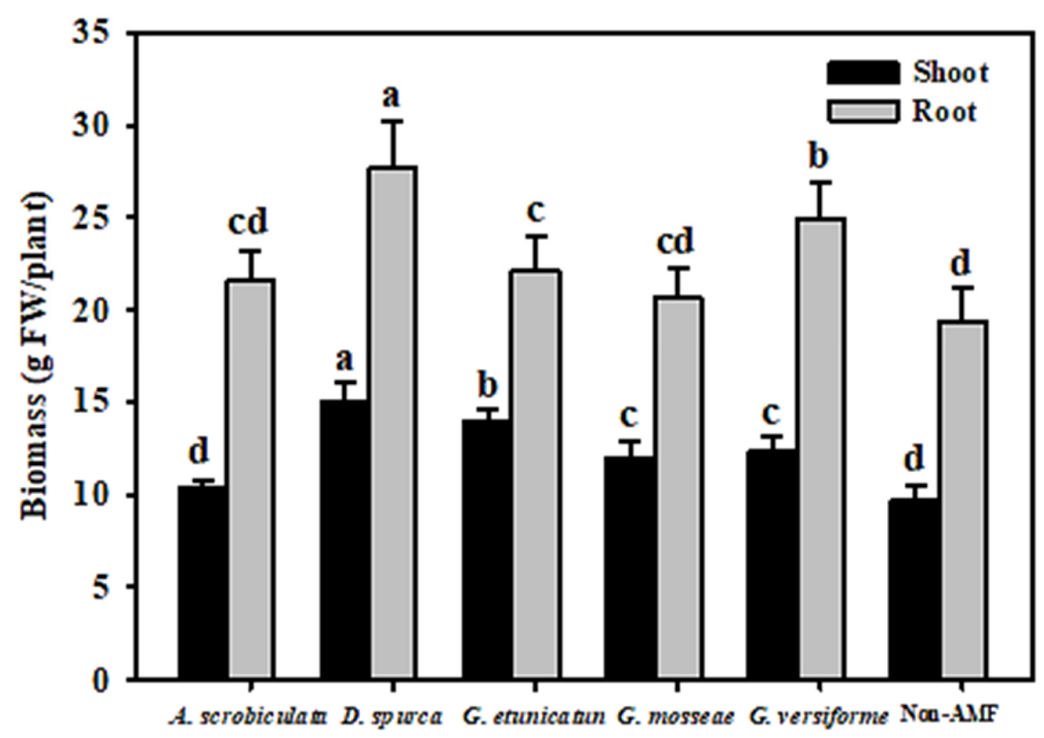

Figure 2. Shoot and root biomass of walnut (Juglans regia L. Liaohe 1) seedlings after inoculated with Acaulospora scrobiculata, Diversispora spurca, Glomus etunicatum, G. mosseae, G. versiforme, and nonAMF

Data (means $\pm \mathrm{SD}, n=6)$ followed by different letters above the bars indicate significant differences $(P<0.05)$ among treatments.

\section{Changes in leaf glucose, fructose and sucrose contents}

As shown in Table 2, inoculation with AMF had different effects on leaf glucose, sucrose, and fructose contents of walnut. After walnut was inoculated with A. scrobiculata, D. spurca, G. etunicatum, G. mosseae, and $G$. versiforme, leaf glucose contents were significantly decreased by $43.9 \%, 14.7 \%, 32.2 \%, 31.4 \%$ and $42.7 \%$, and leaf fructose contents were reduced by $46.7 \%, 30.6 \%, 15.0 \%, 53.0 \%$ and $31.7 \%$, respectively. Inoculation of $G$. mosseae did not affect the glucose content in leaves, whereas inoculation with A. scrobiculata, D. spurca, $G$. etunicatum, and $G$. versiforme significantly improved leaf sucrose contents by $65.7 \%, 117.5 \%, 69.9 \%$, and $111.4 \%$, respectively. It is known that AMF growth relies on the photosynthate provided by the host plant (Pfeffer et al., 2010). AMF can only absorb and utilize hexoses such as glucose from the cleavage of sucrose (Wu et al., 2015, 2017). Our result indicated that inoculation of AMF significantly increased leaf sucrose content in walnut, and then higher sucrose content in mycorrhizal plants was conducive to the downward transport through the phloem to the root system, for the growth of AMF (Sonia et al., 2010). At the same time, AMF also dramatically reduced leaf glucose and fructose contents of walnut, because the presence of root mycorrhizal carbon pool required a large amount of glucose. 
Table 2. Leaf chlorophyll fractions (chlorophyll $a$, chlorophyll $b$, total chlorophyll, and carotenoid) and sugar fractions (glucose, fructose, and sucrose) contents of walnut (Juglans regia L. Liaohe 1) seedlings after inoculated with Acaulospora scrobiculata, Diversispora spurca, Glomus etunicatum, $G$. mosseae, $G$. versiforme, and non-AMF

\begin{tabular}{|c|c|c|c|c|c|c|c|}
\hline \multirow{2}{*}{$\begin{array}{c}\text { AMF } \\
\text { treatments }\end{array}$} & \multicolumn{4}{|c|}{ Chlorophyll contents $(\mathrm{mg} / \mathrm{g} \mathrm{FW})$} & \multicolumn{3}{|c|}{ Sugar contents $(\mathrm{mg} / \mathrm{g} \mathrm{DW})$} \\
\hline & Chlorophyll a & Chlorophyll $b$ & Carotenoid & $\begin{array}{c}\text { Total } \\
\text { chlorophyll }\end{array}$ & Glucose & Fructose & Sucrose \\
\hline $\begin{array}{c}\text { A. } \\
\text { scrobiculata }\end{array}$ & $1.36 \pm 0.11 \mathrm{c}$ & $0.65 \pm 0.04 \mathrm{c}$ & $0.45 \pm 0.03 b$ & $2.00 \pm 0.11 \mathrm{c}$ & $37.08 \pm 2.25 \mathrm{~d}$ & $83.29 \pm 11.11 \mathrm{c}$ & $177.78 \pm 7.39 b$ \\
\hline $\begin{array}{c}D . \\
\text { spurca }\end{array}$ & $1.53 \pm 0.10 b$ & $0.72 \pm 0.06 b c$ & $0.53 \pm 0.04 \mathrm{a}$ & $2.25 \pm 0.10 \mathrm{~b}$ & $56.41 \pm 4.44 b$ & $108.53 \pm 7.25 c$ & $233.42 \pm 3.74 \mathrm{a}$ \\
\hline $\begin{array}{c}G . \\
\text { etunicatum }\end{array}$ & $1.65 \pm 0.14 \mathrm{ab}$ & $0.79 \pm 0.03 a$ & $0.55 \pm 0.04 \mathrm{a}$ & $2.44 \pm 0.15 a$ & $44.88 \pm 3.18 c$ & $132.85 \pm 7.44 b$ & $182.39 \pm 7.31 b$ \\
\hline $\begin{array}{c}G . \\
\text { mosseae }\end{array}$ & $1.68 \pm 0.10 \mathrm{a}$ & $0.77 \pm 0.07 \mathrm{ab}$ & $0.53 \pm 0.05 a$ & $2.44 \pm 0.06 \mathrm{a}$ & $45.37 \pm 3.71 \mathrm{c}$ & $73.42 \pm 6.81 \mathrm{~d}$ & $113.25 \pm 9.05 \mathrm{c}$ \\
\hline $\begin{array}{c}G . \\
\text { versiforme }\end{array}$ & $1.19 \pm 0.04 \mathrm{~d}$ & $0.80 \pm 0.07 \mathrm{a}$ & $0.39 \pm 0.03 c$ & $1.98 \pm 0.10 \mathrm{c}$ & $37.90 \pm 4.16 \mathrm{~d}$ & $106.77 \pm 8.50 \mathrm{c}$ & $226.84 \pm 39.20 a$ \\
\hline Non-AMF & $1.00 \pm 0.05 \mathrm{e}$ & $0.47 \pm 0.04 \mathrm{~d}$ & $0.35 \pm 0.03 c$ & $1.47 \pm 0.06 \mathrm{~d}$ & $66.15 \pm 3.53 a$ & $156.28 \pm 5.66 \mathrm{a}$ & $107.32 \pm 13.83 c$ \\
\hline
\end{tabular}

Data (means $\pm \mathrm{SD}, n=4)$ followed by different letters above the bars indicate significant differences $(P<0.05)$ among treatments.

Table 3. Leaf mineral element contents of walnut (Juglans regia L. Liaohe 1) seedlings after inoculated with Acaulospora scrobiculata, Diversispora spurca, Glomus etunicatum, G. mosseae, G. versiforme, and non-AMF

\begin{tabular}{|c|c|c|c|c|c|c|c|c|c|c|}
\hline $\begin{array}{c}\text { AMF } \\
\text { treatments }\end{array}$ & $\underset{(\mathrm{mg} / \text { plant })}{\mathrm{N}}$ & $\mathrm{P}$ (mg/plant) & $\underset{(\mathrm{mg} / \text { plant })}{\mathrm{K}}$ & $\begin{array}{c}\mathrm{Ca} \\
\text { (mg/plant) }\end{array}$ & $\begin{array}{c}\mathrm{Mg} \\
\text { (mg/plant) }\end{array}$ & $\mathrm{Fe}(\mu \mathrm{g} /$ plant $)$ & B ( $\mu \mathrm{g} /$ plant $)$ & $\begin{array}{c}\mathrm{Zn} \\
(\mu \mathrm{g} / \text { plant })\end{array}$ & $\begin{array}{c}\mathrm{Cu} \\
(\mu \mathrm{g} / \text { plant })\end{array}$ & $\begin{array}{c}\text { Mn } \\
\text { ( } \mu \mathrm{g} / \text { plant })\end{array}$ \\
\hline $\begin{array}{c}A . \\
\text { scrobiculata }\end{array}$ & $65.76 \pm 4.75 b$ & $3.41 \pm 0.12 \mathrm{~d}$ & $59.10 \pm 4.54 \mathrm{~b}$ & $\begin{array}{c}56.91 \pm 4.81 \mathrm{c} \\
\mathrm{d}\end{array}$ & $\begin{array}{c}10.15 \pm \\
0.46 \mathrm{ab}\end{array}$ & $1.47 \pm 0.15 b$ & $\begin{array}{l}259.08 \\
\pm 9.07 \mathrm{~b} \\
\end{array}$ & $\begin{array}{c}178.74 \pm 16.4 \\
9 \mathrm{~b}\end{array}$ & $\begin{array}{c}782.62 \pm 18.8 \\
9 \mathrm{c}\end{array}$ & $\begin{array}{c}583.42 \pm 10.1 \\
3 \mathrm{a}\end{array}$ \\
\hline D. spurca & $80.44 \pm 3.12 a$ & $6.38 \pm 0.51 \mathrm{a}$ & $65.58 \pm 5.94 a$ & $78.94 \pm 4.65 \mathrm{a}$ & $\begin{array}{r}10.36 \pm \\
0.99 \mathrm{ab} \\
\end{array}$ & $2.71 \pm 0.17 \mathrm{a}$ & $\begin{array}{c}391.90 \pm 38.4 \\
2 \mathrm{a} \\
\end{array}$ & $\begin{array}{c}196.20 \pm 16.8 \\
4 \mathrm{~b}\end{array}$ & $\begin{array}{c}439.19 \pm 34.6 \\
9 \mathrm{~d}\end{array}$ & $\begin{array}{c}510.50 \pm 38.4 \\
5 b\end{array}$ \\
\hline $\begin{array}{c}G . \\
\text { etunicatum }\end{array}$ & $75.76 \pm 6.13 a$ & $4.73 \pm 0.44 \mathrm{~b}$ & $69.90 \pm 4.79 \mathrm{a}$ & $67.17 \pm 4.14 b$ & $\begin{array}{c}11.13 \pm \\
0.79 \mathrm{a}\end{array}$ & $1.67 \pm 0.08 \mathrm{~b}$ & $\begin{array}{c}209.53 \pm 12.3 \\
2 \mathrm{c}\end{array}$ & $\begin{array}{c}188.61 \pm 15.0 \\
5 \mathrm{~b}\end{array}$ & $\begin{array}{c}1057.17 \pm 58 \\
60 \mathrm{a}\end{array}$ & $\begin{array}{c}453.58 \pm 39.7 \\
6 \mathrm{c}\end{array}$ \\
\hline G. mosseae & $\begin{array}{c}59.87 \pm 1.43 b \\
c\end{array}$ & $4.11 \pm 0.19 \mathrm{c}$ & $52.35 \pm 2.97 \mathrm{c}$ & $66.27 \pm 2.58 \mathrm{~b}$ & $9.43 \pm 1.43 \mathrm{~b}$ & $1.70 \pm 0.14 \mathrm{~b}$ & $\begin{array}{c}217.31 \pm 4.16 \\
c\end{array}$ & $\begin{array}{c}292.10 \pm 14.3 \\
0 \mathrm{a} \\
\end{array}$ & $\begin{array}{c}978.60 \pm 43.8 \\
3 \mathrm{~b} \\
\end{array}$ & $\begin{array}{c}504.59 \pm 8.59 \\
\text { b }\end{array}$ \\
\hline $\begin{array}{c}G . \\
\text { versiforme }\end{array}$ & $75.67 \pm 4.45 a$ & $3.92 \pm 0.32 \mathrm{c}$ & $48.39 \pm 2.22 \mathrm{c}$ & $52.57 \pm 3.16 \mathrm{~d}$ & $\begin{array}{l}9.82 \pm \\
0.70 \mathrm{ab} \\
\end{array}$ & $2.74 \pm 0.22 \mathrm{a}$ & $\begin{array}{c}232.46 \pm 17.2 \\
9 \mathrm{bc}\end{array}$ & $\begin{array}{c}197.88 \pm 12.1 \\
4 \mathrm{~b}\end{array}$ & $\begin{array}{c}440.05 \pm 25.1 \\
8 \mathrm{~d}\end{array}$ & $\begin{array}{c}467.17 \pm 23.9 \\
0 \mathrm{bc}\end{array}$ \\
\hline Non-AMF & $56.42 \pm 5.14 \mathrm{c}$ & $2.84 \pm 0.19 \mathrm{e}$ & $39.86 \pm 3.61 \mathrm{~d}$ & $58.60 \pm 0.79 c$ & $7.48 \pm 0.23 c$ & $1.17 \pm 0.11 \mathrm{c}$ & $\begin{array}{c}115.84 \pm 10.4 \\
1 \mathrm{~d}\end{array}$ & $99.62 \pm 9.47 \mathrm{c}$ & $\begin{array}{c}327.00 \pm 17.6 \\
0 \mathrm{e} \\
\end{array}$ & $\begin{array}{c}611.32 \pm 31.3 \\
4 \mathrm{a} \\
\end{array}$ \\
\hline
\end{tabular}

Data (means \pm SD, $n=4)$ followed by different letters above the bars indicate significant differences $(P<0.05)$ among treatments.

\section{Changes in leaf nutrient contents}

AM symbiosis plays an important role in improving nutritional acquisition of host plants (Hodge et al., 2010). Compared with non-AMF inoculation, inoculation with different AMF species notably improved leaf $\mathrm{K}$ and $\mathrm{P}$ content (Table 3 ), whilst the greatest effect was found in $G$. etunicatum for K improvement and $D$. spurca for P improvement among five AMF treatments. Previous studies have shown that AMF-improved K and P contents were dependent on host plant species, AMF species, and soil environment (Diop et al., 2003; Veresoglou et al., 2011; Kilpeläinen et al., 2020). The reason why AMF promote K and P absorption of host plants may be due to the fact that mycorrhizal extraradical hyphae can extend into the soil inaccessible to the root system. In addition, AMF up-regulated mycorrhiza-specific $\mathrm{P}$ transporter genes to promote the $\mathrm{P}$ absorption by cells (Amijee et al., 1989). The mycorrhizal extraradical hyphae directly secretes phosphatase and indirectly promotes the root system to secrete organic acid to hydrolyze organophosphorus to inorganic phosphorus, all of these ways promote the uptake of P by plants (Duan et al., 2015; Perumalsamy et al., 2017).

In the present study, except that the $G$. mosseae treatment did not affect leaf $N$ concentrations, the other AMF inoculations notably increased leaf $\mathrm{N}$ concentrations, compared to non-AMF control (Table 3). Herein, D. spurca inoculation exhibited the highest effect. A similar result is also found in the maize infected with $G$. intraradices, Acaulospora laevis, and Gigaspora margarita (Frey and Hannes, 1993) and white clover (Xie et al., 2020). It has been suggested that in AM plants, ammonium nitrogen was mainly absorbed by extraradical 
hyphae and then synthesized into arginine, which was moved to the intraradical hyphae into urea and ornithine; the ornithine was catalyzed into amino acids and then proteins in root cells (Bago et al., 2001; Govindarajulu et al., 2005; Jin et al., 2005; Johansen and Olsson, 2006; Xie et al., 2020).

All the AMF treatments significantly promoted leaf $\mathrm{Ca}, \mathrm{Mg}, \mathrm{B}, \mathrm{Fe}, \mathrm{Zn}$, and $\mathrm{Cu}$ contents, except the reduction of Ca after $G$. versiforme treatment. Hereinto, D. spurca had the best promotion on Ca and B content, $G$. etunicatum had the strongest positive effect on $\mathrm{Mg}$ and $\mathrm{Cu}$ contents, $G$. versiforme had the best promotion on $\mathrm{Fe}$, and $G$. mosseae had the best acceleration on $\mathrm{Zn}$ content. The important role of the soil AMF mycelium in absorbing mineral elements has been well documented (Labidi et al., 2015; Weisany et al., 2016; Tran et al., 2019; Wu et al., 2019). Earlier studies also showed that AMF had negative effects on Mn content (Arines et al., 1990; Liu et al., 2000). We also found the negative effect on leaf Mn content after AMF inoculation, except $A$. scrobiculata. The reduction of Mn under mycorrhization is mainly because AMs reduce the amount of manganese reductants (Liu et al., 2000). Among five AMF species, D. spurca and G. etunicatum showed better promotion on $\mathrm{Ca}, \mathrm{Mg}, \mathrm{B}, \mathrm{Fe}, \mathrm{Zn}$ and $\mathrm{Cu}$ acquisition than other AMF species, which is in line with the corresponding root mycorrhizal colonization.

\section{Conclusions}

Mycorrhizal fungi could colonize roots of walnut and also positively accelerated shoot and root biomass production and improved physiological activities with regard to leaf chlorophyll production, leaf sucrose accumulation, and leaf nutrient acquisition (e.g., $\mathrm{P}, \mathrm{K}, \mathrm{Mg}, \mathrm{B}, \mathrm{Fe}, \mathrm{Zn}$, and $\mathrm{Cu}$ ), dependent on AMF species. Hereinto, Diversispora spurca represented the best effect. These results provide critical support for the application of AMF in walnut in the future.

\section{Authors' Contributions}

Conceptualization: YJX and QSW; Data curation: GMH and WJC. Formal analysis: WJC, YJX, and QSW; Funding acquisition: YJX; Investigation: GMH and ZYX; Methodology: GMH and WJC; Project administration: YJX; Supervision: YJX and QSW; Writing - original draft: GMH and WJC; Writing - review and editing: MMR and QSW. All authors read and approved the final manuscript.

\section{Acknowledgements}

This work was supported by the Local Special Project for Science and Technology Development guided by the central government (2018ZYYD045).

\section{Conflict of Interests}

The authors declare that there are no conflicts of interest related to this article. 


\section{References}

Adolfsson L, Nziengui H, Abreu IN, Šimura J, Beebo A, Herdean A (2017). Enhanced secondary and hormone metabolism in leaves of arbuscular mycorrhizal Medicago truncatula. Plant Physiology 175:392-411. https://doi.org/10.1104/pp.16.01509

Amijee F, Tinker PB, Stribley DP (1989). Effects of phosphorus on the morphology of VA mycorrhizal root system of leek (Allium porrum L.). Plant and Soil 119:334-336. https://doi.org/10.1007/BF02370427

Arines J, Vilarino A, Sainz M (1990). Effect of vesicular-arbuscular mycorrhizal fungi on Mn uptake by red clover. Agriculture, Ecosystems and Environment 29:1-4. https://doi.org/10.1007/s005720050302

Arnon DI (1949). Copper enzymes in isolated chloroplasts. Polyphenol oxidase in Beta vulgaris. Plant Physiology 24:115. https://doi.org/10.1104/pp.24.1.1

Bago B, Pfeffer P, Shachar-Hill Y (2001). Could the urea cycle be translocating nitrogen in the arbuscular mycorrhizal symbiosis?. New Phytologist 149:4-8. https://doi.org/10.1046/j.1469-8137.2001.00016.x

Baslam M, Esteban R, García-Plazaola JI, Goicoechea N (2013). Effectiveness of arbuscular mycorrhizal fungi (AMF) for inducing the accumulation of major carotenoids, chlorophylls and tocopherol in green and red leaf lettuces. Applied Microbiology and Biotechnology 97:3119-3128. https://doi.org/10.1007/s00253-012-4526-X

Behrooz A, Vahdati K, Rejali F, Lotfi M, Leslie C (2019). Arbuscular mycorrhiza and plant growth-promoting bacteria alleviate drought stress in walnut. HortScience 54:1087-1092. https://doi.org/10.21273/HORTSCI13961-19

Bethlenfalvay GJ, Ames RN (1987). Comparison of two methods for quantifying extraradical mycelium of vesiculararbuscular mycorrhizal fungil. Soil Science Society of America Journal 51:834-837.

Bradford MM (1976). A rapid and sensitive method for the quantitation of microgram quantities of protein utilizing the principle of protein-dye binding. Analytical Biochemistry 72:248-252.

Bu WS, Chen FS, Wang FC, Fang XM, Wang HM (2019). The species-specific responses of nutrient resorption and carbohydrate accumulation in leaves and roots to nitrogen addition in a subtropical mixed plantation. Canadian Journal of Forest Research 49:1-27.

Curaqueo G, Acevedo E, Cornejo P, Seguel A, Rubio R, Borie F (2010). Tillage effect on soil organic matter, mycorrhizal hyphae and aggregates in a mediterranean agroecosystem. Journal of Soil Science and Plant Nutrition 10:12-21. https://doi.org/10.4067/S0718-27912010000100002

Davoodian N, Bosworth J, Rajakaruna N (2012). Mycorrhizal colonization of Hypericum perforatum L. (Hypericaceae) from serpentine and granite outcrops on the Deer Isles, Maine. Northeastern naturalist 19:517-526.

Diop TA, Krasova-Wade T, Diallo A, Diouf M, Gueye M (2003). Solanum cultivar responses to arbuscular mycorrhizal fungi: growth and mineral status. African Journal of Biotechnology 2:429-433.

Dixon RK (1988). Seed source and vesicular-arbuscular mycorrhizal symbiont affects growth of Juglans nigra seedlings. New Forests 2:203-211. https://doi.org/10.1007/BF00029989

Dolcet-Sanjuan R, Claveria E, Camprubí A, Estaún V, Calvet C (1996). Micropropagation of walnut trees (Juglans regia L.) and response to arbuscular mycorrhizal inoculation. Agronomie 16:639-645.

Duan J, Tian H, Drijber RA, Gao Y (2015). Systemic and local regulation of phosphate and nitrogen transporter genes by arbuscular mycorrhizal fungi in roots of winter wheat (Triticum aestivum L.) Plant Physiology and Biochemistry 96:199-208. https://doi.org/10.1016/j.plaphy.2015.08.006

Ekanayake IJ, Oyetunji OJ, Osonubi O, Lyasse O (2015). The effects of arbuscular mycorrhizal fungi and water stress on leaf chlorophyll production of cassava (Manihot esculenta Crantz). Journal of Food Agriculture and Environment 2:190-196.

Fester T, Wray V, Nimtz M, Strack D (2005). Is stimulation of carotenoid biosynthesis in arbuscular mycorrhizal roots a general phenomenon?. Phytochemistry 66:1781-1786. https://doi.org/10.1016/j.phytochem.2005.05.009

Frey B, Hannes S (1993). Acquisition of nitrogen by external hyphae of arbuscular mycorrhizal fungi associated with $Z e a$ mays L. New Phytologist 124:221-230.

García-González I, Quemada M, Gabriel JL, Hontoria C (2016). Arbuscular mycorrhizal fungal activity responses to winter cover crops in a sunflower and maize cropping system. Applied Soil Ecology 102:10-18. https://doi.org/10.1016/j.apsoil.2016.02.006

García-Rodríguez S, Azcón-Aguilar C, Ferrol N (2010). Transcriptional regulation of host enzymes involved in the cleavage of sucrose during arbuscular mycorrhizal symbiosis. Physiologia Plantarum 129:737-746. https://doi.org/10.1111/j.1399-3054.2007.00873.x 
Gill SS, Gill R, Trivedi DK, Anjum NA, Sharma KK, Sharma KK, ... Tuteja N (2016). Piriformospora indica: potential and significance in plant stress tolerance. Frontiers in Microbiology 7:332. https://doi.org/10.3389/fmicb.2016.00332

Giri B, Kapoor R, Mukerji KG (2003). Influence of arbuscular mycorrhizal fungi and salinity on growth, biomass, and mineral nutrition of Acacia auriculiformis. Biology and Fertility of Soils 38:170-175. https://doi.org/10.1007\%2Fs00374-003-0636-Z

Govindarajulu M, Pfeffer P, Jin H, Abubaker J, Douds D, Allen J (2005). Nitrogen transfer in the arbuscular mycorrhizal symbiosis. Nature 435:819-823. https://doi.org/10.1038/nature03610

He JD, Chi GG, Zou YN, Shu B, Wu QS, Srivastava AK, Kuča K (2020). Contribution of glomalin-related soil proteins to soil organic carbon in trifoliate orange. Applied Soil Ecology 154:103592. https://doi.org/10.1016/j.apsoil.2020.103592

He JD, Dong T, Wu HH, Zou YN, Wu QS, Kuca K (2019). Mycorrhizas induce diverse responses of root TIPaquaporin gene expression to drought stress in trifoliate orange. Scientia Horticulturae 243:64-69. https://doi.org/10.1016/j.scienta.2018.08.010

Hodge A, Helgason T, Fitter AH (2010). Nutritional ecology of arbuscular mycorrhizal fungi. Fungal Ecology 3:267-273. https://doi.org/10.1016/j.funeco.2010.02.002

Ingraffia R, Amato G, Frenda AS, Giambalvo D, Aroca R (2019). Impacts of arbuscular mycorrhizal fungi on nutrient uptake, $\mathrm{N}_{2}$ fixation, $\mathrm{N}$ transfer, and growth in a wheat/faba bean intercropping system. PLoS One 14:e0213672. https://doi.org/10.1371/journal.pone.0213672

Jin H, Pfeffer PE, Douds DD, Piotrowski E, Lammers PJ, Shachar-Hill Y (2005). The uptake, metabolism, transport and transfer of nitrogen in an arbuscular mycorrhizal symbiosis. New Phytologist 168:687-696. https://doi.org/10.1111/j.1469-8137.2005.01536.x

Johansen A, Olsson FPA (2006). Nitrogen metabolism of external hyphae of the arbuscular mycorrhizal fungus Glomus intraradices. New Phytologist 133:705-712.

Kilpeläinen J, Aphalo PJ, Barbero-López A, Bartosz A, Alam NS, Tarja L (2020). Are arbuscular-mycorrhizal Alnus incana seedlings more resistant to drought than ectomycorrhizal and nonmycorrhizal ones?. Tree Physiology 40:782-795. https://doi.org/10.1093/treephys/tpaa035

Kong X, Zhao Y, Tian K, He X, Tian X (2020). Insight into nitrogen and phosphorus enrichment on cadmium phytoextraction of hydroponically grown Salix matsudana Koidz cuttings. Environmental ence and Pollution Research 27:1-12. https://doi.org/10.1007/s11356-019-07499-4

Labidi S, Jeddi FB, Tisserant B, Yousfi M, Sanaa M, Dalpé Y (2015). Field application of mycorrhizal bio-inoculants affects the mineral uptake of a forage legume (Hedysarum coronarium L.) on a highly calcareous soil. Mycorrhiza 25:297-309. https://doi.org/10.1007/s00572-014-0609-0

Latef AAHA and Chaoxing H (2011). Effect of arbuscular mycorrhizal fungi on growth, mineral nutrition, antioxidant enzymes activity and fruit yield of tomato grown under salinity stress. Scientia Horticulturae 127:228-233.

Liu A, Hamel C, Hamilton RI, Ma BL, Smith DL (2000). Acquisition of Cu, Zn, Mn and Fe by mycorrhizal maize (Zea mays L.) grown in soil at different $\mathrm{P}$ and micronutrient levels. Mycorrhiza 9:331-336. https://doi.org/10.1007/s005720050277

López-Ráez JA, Verhage A, Fenández I, García JM, Azcón-Aguilar C, Flors V, Pozo MJ (2010). Hormonal and transcriptional profiles highlight common and differential host responses to arbuscular mycorrhizal fungi and the regulation of the oxylipin pathway. Journal of Experimental Botany 61:2589-2601. https://doi.org/10.1093/jxb/erq089

Mathur S, Sharma MP, Jajoo A (2018). Improved photosynthetic efficacy of maize (Zea mays) plants with arbuscular mycorrhizal fungi (AMF) under high temperature stress. Journal of Photochemistry and Photobiology B: Biology 180:149-154. https://doi.org/10.1016/j.jphotobiol.2018.02.002

Meng LL, He JD, Zou YN, Wu QS, Kuča K (2020). Mycorrhiza-released glomalin-related soil protein fractions contribute to soil total nitrogen in trifoliate orange. Plant, Soil and Environment 66:183-189. https://doi.org/10.17221/100/2020-PSE

Moreira H, Pereira SIA, Vega A, Castro PML, Marques APGC (2019). Synergistic effects of arbuscular mycorrhizal fungi and plant growth-promoting bacteria benefit maize growth under increasing soil salinity. Journal of Environmental Management 257:109982. https://doi.org/10.1016/j.jenvman.2019.109982 
Nagy R, Drissner D, Amrhein N, Bucher JM (2010). Mycorrhizal phosphate uptake pathway in tomato is phosphorusrepressible and transcriptionally regulated. New Phytologist 181:950-959. https://doi.org/10.1111/j.14698137.2008.02721.x

Ortas I, Ortakçi D, Kaya Z, Çinar A, Önelge N (2002). Mycorrhizal dependency of sour orange in relation to phosphorus and zinc nutrition. Journal of Plant Nutrition 25:1263-1279. https://doi.org/10.1081/PLN-120004387

Pati R, Mukhopadhyay D (2009). Effects of organics influencing the arsenic transport in soil-plant systems. Indian Journal of Agricultural Sciences 79:996-999.

Perumalsamy P, Thangavelu M (2017). Arbuscular mycorrhizal fungus influence maize root growth and architecture in rock phosphate amended tropical soil. Anales de Biología 39:211-222. https://doi.org/10.6018/analesbio.39.22

Pfeffer PE, Douds DD, Heike B, Schwartz DP, Shachar-Hill Y (2010). The fungus does not transfer carbon to or between roots in an arbuscular mycorrhizal symbiosis. New Phytologist 163:617-627.

Phillips JM, Hayman DS (1970). Improved procedures for clearing roots and staining parasitic and vesicular-arbuscular mycorrhizal fungi for rapid assessment of infection. Transactions of the British Mycological Society 55:158-161. https://doi.org/10.1016/S0007-1536(70)80110-3

Qin L, Zhang CL, Zhang B (2011) Differential gene expression in leaves and roots of winter rape in response to phosphorus starvation. Russian Journal of Plant Physiology 58:142-148. https://doi.org/10.1134/S1021443710061032

Seguel A, Barea JM, Cornejo P, Borie F (2015). Role of arbuscular mycorrhizal symbiosis in phosphorus-uptake efficiency and aluminium tolerance in barley growing in acid soils. Crop and Pasture science 66:696-705. https://doi.org/10.1071/CP14305

Shao YD, Zhang DJ, Hu XC, Wu QS, Jiang CJ, Xia TJ, Gao XB, Kuča K (2018). Mycorrhiza-induced changes in root growth and nutrient absorption of tea plants. Plant, Soil and Environment 64:283-289. https://doi.org/10.17221/126/2018-PSE

Sun H, Yang F (2019). Effect of arbuscular mycorrhizal fungi on switchgrass growth and mineral nutrition in cadmiumcontaminated soil. Polish Journal of Environmental Studies 29:1369-1377. https://doi.org/10.1371/journal.pone.0196408

Tran BTT, Cavagnaro TR, Watts-Williams SJ (2019). Arbuscular mycorrhizal fungal inoculation and soil zinc fertilisation affect the productivity and the bioavailability of zinc and iron in durum wheat. Mycorrhiza 29:445457.

Treseder Kathleen K (2013). The extent of mycorrhizal colonization of roots and its influence on plant growth and phosphorus content. Plant and Soil 371:1-13. https://doi.org/10.1007/s11104-013-1681-5

Tuo XQ, Li S, Wu QS, Zou YN (2015). Alleviation of waterlogged stress in peach seedlings inoculated with Funneliformis mosseae: Changes in chlorophyll and proline metabolism. Scientia Horticulturae 197:130-134.

Veresoglou SD, Shaw LJ, Sen R (2011). Glomus intraradices and Gigaspora margarita arbuscular mycorrhizal associations differentially affect nitrogen and potassium nutrition of Plantago lanceolata in a low fertility dune soil. Plant and Soil 340:481-490. https://doi.org/10.1007/s11104-010-0619-4

Walder F, Brulé D, Koegel S, Wiemken A, Boller T, Courty PE (2015). Plant phosphorus acquisition in a common mycorrhizal network: regulation of phosphate transporter genes of the Pht 1 family in sorghum and flax. New Phytologist 205:1632-1645. https://doi.org/10.1111/nph.13292

Wang H, He Z, Zhang Z, Yang C (2016). Xylem ion balance in tomato plants under alkali stress. Australian Journal of Crop Science 10:874-877.

Weisany W, Raei Y, Salmasi SZ, Sohrabi Y, Ghassemi-Golezani K (2016). Arbuscular mycorrhizal fungi induced changes in rhizosphere, essential oil and mineral nutrients uptake in dill/common bean intercropping system. Annals of Applied Biology 169:384-397. https://doi.org/10.1111/aab.12309

Wu HH, Zou YN, Rahman MM, Ni QD, Wu QS (2017). Mycorrhizas alter sucrose and proline metabolism in trifoliate orange exposed to drought stress. Scientific Reports 7:42389. https://doi.org/10.1038/srep 42389

Wu QS, Gao WQ, Srivastava AK, Zhang F, Zou YN (2020). Nutrient acquisition and fruit quality of Ponkan mandarin in response to AMF inoculation. Indian Journal of Agricultural Sciences 90:1563-1567.

Wu QS, He JD, Srivastava AK, Zhang F, Zou YN (2019a). Development of propagation technique of indigenous AMF and their inoculation response in citrus. Indian Journal of Agricultural Sciences 89:1190-1194.

Wu QS, He JD, Srivastava AK, Zou YN, Kuca K (2019b). Mycorrhizas enhance drought tolerance of citrus by altering root fatty acid compositions and their saturation levels. Tree Physiology 39:1149-1158. https://doi.org/10.1093/treephys/tpz039 
Wu QS, He XH, Zou YN, He KP, Sun YH, Cao MQ (2012). Spatial distribution of glomalin-related soil protein and its relationships with root mycorrhization, soil aggregates, carbohydrates, activity of protease and $\beta$-glucosidase in the rhizosphere of Citrus unshiu. Soil Biology and Biochemistry 45:181-183. https://doi.org/10.1016/j.soilbio.2011.10.002

Wu QS, Srivastava AK, Zou YN (2013). AMF-induced tolerance to drought stress in citrus: A review. Scientia Horticulturae 164:77-87 https://doi.org/10.1016/j.scienta.2013.09.010

Wu QS, Lou YG, Li Y (2015). Plant growth and tissue sucrose metabolism in the system of trifoliate orange and arbuscular mycorrhizal fungi. Scientia Horticulturae 181:189-193. https://doi.org/10.1016/j.scienta.2014.11.006

Xie MM, Zou YN, Wu QS, Zhang ZZ, Kuča K (2020). Single or dual inoculation of arbuscular mycorrhizal fungi and rhizobia regulates plant growth and nitrogen acquisition in white clover. Plant, Soil and Environment 66:287-294. https://doi.org/10.17221/234/2020-PSE

Yang L, Zou YN, Tian ZH, Wu QS, Kuča K (2021). Effects of beneficial endophytic fungal inoculants on plant growth and nutrient absorption of trifoliate orange seedlings. Scientia Horticulturae 277:109815. https://doi.org/10.1016/j.scienta.2020.109815

Zhang F, Zou YN, Wu QS, Kuča K (2020). Arbuscular mycorrhizas modulate root polyamine metabolism to enhance drought tolerance of trifoliate orange. Environmental and Experimental Botany 171:103962. https://doi.org/10.1016/j.envexpbot.2019.103926

Zou J, Shang X, Li C, Ouyang J, Li B, Liu X (2019). Effects of cadmium on mineral metabolism and antioxidant enzyme activities in Salix matsudana Koidz. Polish Journal of Environmental Studies 28:989-999.

Zou YN, Wu QS, Kuča K (2020). Unravelling the role of arbuscular mycorrhizal fungi in mitigating the oxidative burst of plants under drought stress. Plant Biology. https://doi.org/10.1111/plb.13161

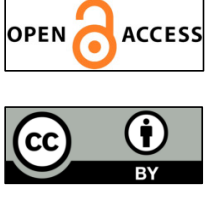

The journal offers free, immediate, and unrestricted access to peer-reviewed research and scholarly work. Users are allowed to read, download, copy, distribute, print, search, or link to the full texts of the articles, or use them for any other lawful purpose, without asking prior permission from the publisher or the author.

License - Articles published in Notulae Botanicae Horti Agrobotanici Cluj-Napoca are Open-Access, distributed under the terms and conditions of the Creative Commons Attribution (CC BY 4.0) License.

(c) Articles by the authors; UASVM, Cluj-Napoca, Romania. The journal allows the author(s) to hold the copyright/to retain publishing rights without restriction. 